\title{
Article
}

\section{Converting Units}

Davies, Janice Anne

Available at http://clok.uclan.ac.uk/29630/

Davies, Janice Anne (2019) Converting Units. Journal of Prescribing Practice, 1 (9). ISSN 2631-8385

It is advisable to refer to the publisher's version if you intend to cite from the work.

10.12968/jprp.2019.1.9.432

For more information about UCLan's research in this area go to

http://www.uclan.ac.uk/researchgroups/ and search for <name of research Group>.

For information about Research generally at UCLan please go to http://www.uclan.ac.uk/research/

All outputs in CLoK are protected by Intellectual Property Rights law, including Copyright law. Copyright, IPR and Moral Rights for the works on this site are retained by the individual authors and/or other copyright owners. Terms and conditions for use of this material are defined in the policies page.

\section{CLoK}

Central Lancashire online Knowledge www.clok.uclan.ac.uk

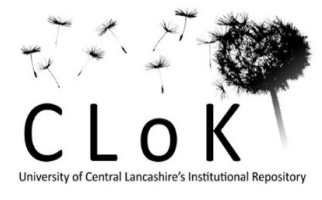


As a prescriber you may encounter doses of medicines that are expressed in either grams, milligrams or micrograms. You may encounter volumes of medicines that are expressed in litres, millilitres or occasionally microlitres when referring to a very small quantity such as a small number of drops of liquid.

It is important to understand the relationship between these units of mass and volume. The examples in this article provides some practice in converting units.

For the purpose of drug calculations the Standard International (SI) units used will relate to mass and volume:

Mass - the SI unit used to measure mass is the "gram"

Volume - the SI unit used to measure volume is the "litre"

\section{Prefixes}

\begin{tabular}{|l|l|l|}
\hline SIZE & PREFIX & SYMBOL \\
\hline One Hundredth & centi & $\mathrm{c}$ \\
\hline One thousandth & milli & $\mathrm{m}$ \\
\hline One millionth & micro & micro, $\mu$ \\
& & \\
\hline
\end{tabular}

SI units with prefix

\begin{tabular}{|l|l|l|l}
\hline Kilogram $(\mathrm{kg})$ & GRAM $(\mathrm{g})$ & milligram $(\mathrm{mg})$ & microgram $(\mathrm{mcg})$ \\
& & & \\
& & & \\
\hline
\end{tabular}




\begin{tabular}{|l|l|l|l|}
\hline Kilolitre & LITRE (l) & millilitre $(\mathrm{ml})$ & Microlitre $(\mathrm{mcl})$ \\
& & & \\
\hline
\end{tabular}

Units of weight and volume

1 kilogram $=1000$ grams

1 gram $=1000$ milligrams

1 milligram $=1000$ micrograms

1 litre $=1000$ millilitres

To convert from larger to smaller units we multiply by 1000 for each step

To convert from smaller to larger we divide by 1000

Now try these exercises.

Convert:
a) $250 \mathrm{mg}$ to $\mathrm{g} \quad 0.25 \mathrm{~g}$
b) $0.7 \mathrm{~g}$ to $\mathrm{mg} \quad 700 \mathrm{mg}$
c) $50 \mathrm{ml}$ to litres $0.05 \mathrm{I}$
d) 2 litres to $\mathrm{ml} \quad 2000 \mathrm{ml}$
e) $568 \mathrm{mls}$ to litres 0.5681
f) 400 micrograms to $\mathrm{mg} \quad 0.4 \mathrm{mg}$
g) 893 micrograms to $\mathrm{mg} \quad 0.893 \mathrm{mg}$
h) $0.63 \mathrm{~g}$ to $\mathrm{mg} \quad 630 \mathrm{mg}$
i) $2.5 \mathrm{~kg}$ to g $2500 \mathrm{~g}$ 